\title{
Infiltration and Sediment Rates Following Creosotebush Control With Tebuthiuron
}

\author{
Steven R. Perkins ${ }^{1}$ and Kirk C. McDaniel ${ }^{2}$ \\ Authors are ${ }^{1}$ Area Range Specialist, USDA-NRCS, Victorville, CA 92395; and ${ }^{2}$ Professor, Department of Animal and \\ Range Sciences, New Mexico State University, Las Cruces, NM 88003.
}

\begin{abstract}
The effects of chemical creosotebush (Larrea tridentata [D.C.] Cov.) control on infiltration rates, wetting-front depth, and sediment production were examined in the Chihuahuan Desert of southern New Mexico. Study sites were treated with aerial applications of tebuthiuron (N-[5-(1,1-dimethylethyl)-1,3,4-thiadiazol-2-yl]-N, $\mathrm{N}^{\prime}$-dimethylurea) as part of a brush control program administered by the US Bureau of Land Management. Study sites were equally distributed among 3 geographic regions and included 6 sites treated 5-9 years ago, 6 sites treated 15-18 years ago, and 12 contiguous nontreated sites. Paired $1-\mathrm{m}^{2}$ rainfall simulation plots encompassed the creosotebush canopy zone and adjacent interspace area with runs made using simulated rainfall at $9.1 \mathrm{~cm} \cdot \mathrm{hr}^{-1}$ for 30 minutes. Runoff and sediment were collected every 5 minutes, and wetting-front depths were measured at the end of rainfall simulations. Infiltration rates were significantly higher in the canopy zone than in interspace areas and were highest in 5-9-year-old sites, intermediate in nontreated sites, and lowest in 15-18-year-old sites. Regression equations showed that infiltration rates within the canopy zone were positively correlated with litter mass, and cover of litter, shrubs, and grasses. Within interspace areas, infiltration rates were most correlated with aggregate stability and cover of litter, rocks, and grasses. Wetting-front depths were significantly deeper in the canopy zone than in interspace areas for all treatments. Sediment concentration $\left(\mathrm{kg} \cdot \mathrm{L}^{-1}\right)$ was higher in the canopy zone than interspace, but total sediment yield was not significantly different between these areas or affected by any treatments.
\end{abstract}

\section{Resumen}

Se examinaron los efectos del control químico del "Creosotebush" (Larrea tridentata (D.C.) Cov.) sobre las tasas de infiltración, profundidad del frente húmedo y producción de sedimentos en el Desierto Chihuahuense del Sur de Nuevo Mexico. Los sitios de estudio se trataron con aplicaciones aéreas de tebuthiuron ( $\mathrm{N}$-[5-(1,1-dimetiletil)-1,3,4-tiadiazol-2-yl]-N,N'-dimetilurea) como parte de un programa de control de arbustos administrado pro el Buró de Manejo de Tierras de EE.UU. Los sitios de estudio fuero distribuidos equitativamente entre 3 regiones geográficas e incluyeron 6 sitios tratados 5-9 años antes, 6 sitios tratados 15-18 años antes y 12 sitios contiguos no tratados. Se Usaron parcelas apareadas de $1 \mathrm{~m}^{2}$ para simulación de lluvia que abarcaron la zona de la copa del "Creosotebush" y el área del espacio entre plantas adyacente y se hicieron corridas usando lluvia simulada a razón de $9.1 \mathrm{~cm} \cdot \mathrm{hr}^{-1}$ por 30 minutes. El escurrimiento y los sedimentos fueron colectados cada 5 minutos y las profundidades del frente húmedo fueron medidas al final de las simulaciones de lluvia. Las tasas de infiltración fueron significativamente mayores en la zona de la copa que en el área del espacio entre plantas y las mayores tasas fueron en los sitios con 5-9 años de haber sido tratados y las menores en los sitios con 15-18 años de antigüedad. Las ecuaciones de regresión mostraron que las tasas de infiltración dentro de la zona de la copa estuvieron positivamente correlacionadas con la masa de mantillo, arbustos y zacates. En las áreas entre plantas las tasas de infiltración estuvieron más correlacionadas con la estabilidad de los agregados y cobertura de mantillo, rocas y zacates. Las profundidades del frente húmedo fueron significativamente más profundas en la zona de la copa que en las áreas entre plantas, esto fue igual en todos los tratamientos. La concentración de sedimentos $\left(\mathrm{kg} \cdot \mathrm{L}^{-1}\right)$ fue mayor en la zona de la copa que en el área entre plantas, pero el rendimiento total de sedimentos no fue significativamente diferente entre estas áreas o las afectadas por cualquiera de los tratamientos.

Key Words: brush control, erosion, Larrea tridentata, rainfall simulator, wetting front

\section{INTRODUCTION}

Research was supported by New Mexico State University's Agricultural Experiment Station and the Las Cruces District, Bureau of Land Management.

Mention of a proprietary product does not constitute a guarantee or warranty of the product and does not imply its approval to the exclusion of the other products that also may be suitable.

At the time of this research, the senior author was research assistant, Dept of Animal and Range Sciences, New Mexico State University, Las Cruces, NM 88003.

Correspondence: Kirk McDaniel, Dept of Animal and Range Sciences, P0 Box 30003, MSC 3-I, New Mexico State University, Las Cruces, NM 88003. E-mail: kmcdanie@ nmsu.edu

Manuscript received 3 March 2005; manuscript accepted 26 July 2005.
Creosotebush (Larrea tridentata [D.C.] Cov.) has increased over the last century in many areas that were once predominantly grasslands in the Chihuahuan Desert of southern New Mexico (Buffington and Herbel 1965; Grover and Musick 1990; Van Auken 2000). This shift from a grass-dominated to a woodydominated community has likely changed the spatial and temporal distribution of soil resources (Schlesinger et al. 1990) and altered hydrologic processes (Abrahams et al. 1994; Quinton et al. 1997; Dunkerley and Booth 1999; Parizek et al. 2002). In shrub-dominated communities, organic resources 
typically become concentrated under shrubs, and wind and water remove organic materials from intershrub areas. Whitford (1997; 2002) has characterized the sequestering of nutrients beneath creosotebush canopies as creating islands of fertility.

Infiltration rates directly beneath woody plant canopies are usually higher than in interspace or open areas between shrubs (Dee et al. 1966; Tromble et al. 1974; Thurow et al. 1986). This results partially from the buildup of litter material around the shrub in comparison to intershrub areas, which are sparsely covered with herbaceous material (Blackburn et al. 1992). In general, increasing plant and other organic cover reduces raindrop impacts and enhances water infiltration, whereas a decline in plant cover increases runoff and soil erosion rates (Tadmor and Shanan 1969; Bergkamp 1998). Across broad landscapes the relative proportion of grass to shrub cover is usually a key factor affecting runoff and soil erosion (Martin and Morton 1993; Parizek et al. 2002), though this is not always the case (Mergen et al. 2001). Tromble et al. (1974) reported lower runoff in creosotebush communities than from native grasslands, but Abrahams et al. (1996) reported higher runoff in areas that shifted from grass- to creosotebushdominated communities.

In an effort to remove creosotebush and restore native grasslands in southern New Mexico, the Las Cruces and Socorro districts of the US Bureau of Land Management (BLM) have been engaged in an annually administered largescale brush control program since the early 1980s. The annual program involves aerial application of tebuthiuron $(\mathrm{N}-[5-(1,1-$ dimethylethyl)-1,3,4-thiadiazol-2-yl]-N, $\mathrm{N}^{\prime}$-dimethylurea) to selected rangeland pastures throughout the districts. Tebuthiuron effectively controls creosotebush (Jacoby et al. 1982; Herbel et al. 1985) and enhances grass establishment (Cox et al. 1986; Morton et al. 1990). Wood et al. (1991) investigated the influence of this practice the first 4 years after creosotebush was controlled by tebuthiuron and reported a decline in sediment yield and runoff compared with untreated rangeland. Longer-term effects of creosotebush control on hydrologic processes have not to our knowledge been investigated.

Our primary objective for this research was to examine differences in infiltration and sediment rates in areas where tebuthiuron treatments had been applied up to 18 years earlier. We specifically wanted to determine how infiltration and sediment rates might be modified after creosotebush control within the shrubs' canopy zone and in the adjacent intershrub area. We hypothesized that 1) infiltration rates in the creosotebush canopy zone would be highest in untreated areas and would decrease in treated areas with time, 2) infiltration rates in the interspace area would be lowest in untreated areas and increase in treated areas with time, 3) sediment yield in the creosotebush canopy zone would be lowest in untreated areas and increase in treated areas with time, and 4) sediment yield in the interspace area would be highest in untreated areas and decrease in treated areas with time.

\section{STUDY AREA AND METHODS}

The Las Cruces and Socorro offices of the BLM initiated their brush control program in 1981 to reduce creosotebush dominance on southwestern New Mexico public rangelands. The brush control program involves aerial application of tebuthiuron at the active ingredient rate of 0.56 to $0.84 \mathrm{~kg} \cdot \mathrm{ha}^{-1}$ and has, on average, provided about $85 \%$ creosotebush mortality (Perkins 2003). Grass cover increased following creosotebush control, with shortgrasses establishing first and midgrasses becoming more dominant with plant succession (Perkins 2003).

As of 2001, the BLM had applied tebuthiuron treatments to 67 separate locations, and for this study, 12 sites were randomly selected. Four sites were from each of 3 geographic regions having distinct vegetation communities (Perkins 2003). Geographic regions included the western edge of the San Andres Mountains, a creosotebush-mesquite (Prosopis glandulosa Torrey)/bush muhly (Mublenbergia porteri Scribn.)fluffgrass (Dasyochloa pulchella [Kunth] Steudal) community; the western edge of the Mimbres Mountains, a creosotebush-tarbush (Flourensia cernua D.C.)/bush muhly-fluffgrass community; and north of Deming, a creosotebush/bush muhlyfluffgrass community. At each geographic region there were 3 herbicide treatments annotated in this text as follows: 5-9 years, 15-18 years, and no treatment. That is, 2 sites in each region were treated with tebuthiuron 5 to 9 years previous to this study (1993-1997), 2 sites were treated 15 to 18 years previous to this study (1984-1987), and contiguous, untreated areas were sampled next to each herbicide treated site.

According to weather records (World Climate 2002), average precipitation is $240 \mathrm{~mm}$ at both Deming and Truth or Consequences, with approximately 50\% occurring in July, August, and September. Average maximum daily temperature ranges from $35^{\circ} \mathrm{C}$ in July to $13^{\circ} \mathrm{C}$ in January, and average minimum daily temperature ranges from $17^{\circ} \mathrm{C}$ in July to $-4^{\circ} \mathrm{C}$ in January.

\section{Rainfall Simulations}

A portable rainfall simulator (Wilcox 1985; Wilcox et al. 1986) fitted with a 1/4G10 full jet nozzle (Spraying Systems Co, Wheaton, IL) was used to evaluate infiltration and sedimentation rates. Paired rainfall simulation runs were made using tripods that were equipped with nozzles positioned $175 \mathrm{~cm}$ above the soil surface and directed vertically downwards over $1-\mathrm{m}^{2}$ steel-framed circular plots. At each study site, 10 potentially suitable paired sampling locations were first identified and 3 of these were randomly selected to collect infiltration and sedimentation data. Runs were made simultaneously on one plot that encompassed the coppice dune area of a creosotebush (canopy zone) and on another placed in an open area about $2 \mathrm{~m}$ from the edge of the creosotebush canopy (interspace zone). At no-treatment sites, each canopy zone plot was centered over a live creosotebush that was generally 90 to $125 \mathrm{~cm}$ tall and with a canopy diameter of about 110 to $155 \mathrm{~cm}$. At 5-9-year and 15-18-year sites, canopy zone plots were placed over the skeletal branches of creosotebushes presumably killed by the herbicide. Three paired plots (canopy and interspace zones) were randomly placed in treated and untreated areas at each site, for a total of 12 plots per site and 144 plots for the entire study.

Rainfall simulations were conducted from May through August 2002. Simulations were first made under antecedent moisture conditions (dry run) and then about 24 hours later near field capacity (wet run) using procedures similar to that described by Balliette et al. (1986) and Wilcox et al. (1986). The water application rate for dry runs was $10.9 \mathrm{~cm} \cdot \mathrm{hr}^{-1}$; 
water was applied for 30 minutes. A natural rainfall intensity of $10 \mathrm{~cm} \cdot \mathrm{hr}^{-1}$ occurs in this area about every 2 years, but for shorter periods of time. After each dry run, plots were covered with polyethylene plastic to reduce evaporation until the next day's wet run.

Typically, under natural rainfall, there is a decline in the infiltration rate once soil pores fill and runoff is initiated (Bowyer-Bower 1993; Azooz and Arshad 1996). Although this study was conducted during an extended regional drought, there were rare and sporadic rainfall events that may have biased dry run results. Consequently, wet runs were made with soil near field capacity to allow a more equitable comparison of infiltration rates among sites and treatment conditions (Blackburn et al. 1974). Only the results from wet runs conducted on soils near field capacity are reported in this paper. The water application rate for wet runs was $9.1 \mathrm{~cm} \cdot \mathrm{hr}^{-1}$ and rainfall simulations lasted 30 minutes. Initial time to ponding was recorded and runoff was collected at 5-minute intervals. Infiltration rates were calculated as the difference between total water applied and total water collected as runoff during each time period. Infiltration rates during the 25- and 30-minute time periods were averaged to calculate terminal infiltration. Runoff collected during each 5-minute period was bottled separately and later agitated and passed through commercial filter paper to separate sediment. Filter papers were then oven dried, weighed and converted to sediment yield (mass of sediment per unit area, $\mathrm{kg} \cdot \mathrm{ha}^{-1}$ ) and sediment concentration (mass of sediment per unit volume of runoff, $\mathrm{g} \cdot \mathrm{L}^{-1}$ ) (Blackburn et al. 1974). After wet runs were completed, 3 pits (approximately $15-\mathrm{cm}$ diameter) were excavated at the center and north and south edges of each plot to determine wetting-front depth.

\section{Soil and Vegetation Measurements}

Prior to rainfall simulations, a soil sample $(0.5 \mathrm{~kg}, 0-5 \mathrm{~cm}$ depth) was obtained near the outside edge of each plot and stored in a labeled plastic bag to determine gravimetric antecedent moisture content. Surface roughness was measured north-south and east-west in each plot with a relief meter (Kincaid and Williams 1966) that contained 20 pins spaced $5.5 \mathrm{~cm}$ apart. Surface roughness was calculated as the standard deviation of pin lengths $(\mathrm{cm})$ from the relief-meter frame to the soil surface. Five transects were placed in parallel across plots, and a tape was used to measure aerial and basal cover of grasses, forbs, and shrubs, and to measure litter cover, rock/ gravel cover, and bare ground using a procedure similar to that described by Wood et al. (1991).

Following wet-run rainfall simulations, grasses and forbs were clipped $1 \mathrm{~cm}$ from the soil surface, and litter was gathered within each plot and placed separately in paper bags. Grass, forb, and litter samples were then oven-dried at $70^{\circ} \mathrm{C}$ for 24 hours and weighed. In canopy zone plots, the soil sampling point was located midway between the center and edge of the plot. In interspace plots, the soil sampling point was located at the center of the plot. Bulk density samples were taken at 0-5$\mathrm{cm}$ and $10-15-\mathrm{cm}$ depths with a variation of the core method (Blake and Hartge 1986). Bulk density samples were oven-dried for 24 hours at $105^{\circ} \mathrm{C}$ prior to weighing. An additional soil sample $(0.5 \mathrm{~kg}, 0-5 \mathrm{~cm}$ depth) was obtained from each sampling point for lab analyses to determine organic matter, aggregate stability, and textural properties. Organic matter content was mea- sured using the Walkley-Black procedure (Nelson and Sommers 1982). Soil texture was measured with the hydrometer method of particle size analysis (Gee and Bauder 1982) on samples that had been pretreated for organic matter (Anderson 1963).

Aggregate stability was measured with the wet sieve method (Kemper and Rosenau 1986) as modified by Herrick et al. (2001). This method ranks aggregate stability based on soil cohesion when submerged in water. Aggregate stability was also measured using the alcohol drop method (Taylor and Ashcroft 1972), which was designed for use in arid environments where aggregate stability is low. Because the stability of soil aggregates in a liquid is related to the dielectric constant of the liquid, an estimate of aggregate stability can be obtained by treating aggregates from a soil sample with solutions possessing a variety of dielectric constants. Ethyl alcohol and water mixtures were used to generate dielectric constants from 25.6 to 81.7 , and the ratio of ethyl alcohol to water required to cause slaking was taken as an index of aggregate stability. Eleven alcohol-water mixtures were used, ranging from pure ethyl-alcohol to pure water in increments of $10 \%$ by volume. The resulting stability values range from 1 (least stable, aggregate slakes in pure alcohol) to 11 (most stable, pure water required to induce slaking).

\section{Statistical Analysis}

The statistical design is a randomized block analyzed as a splitsplit-split plot. The whole plot consists of 3 geographic regions, the split plot is herbicide treatment, the split-split plot is creosotebush proximity (canopy vs. interspace), and the splitsplit-split plot is time. Infiltration, sediment, and wetting-front depth data were analyzed with a mixed effects model in SAS (SAS Institute Inc 2001). Fixed effects included geographic region and herbicide treatment. Random effects included study site and canopy/interspace zones sampled. The variancecovariance structure of data was analyzed with the generalized linear model procedure in SAS (SAS Institute Inc 2001) to ensure the validity of the split-split-split plot design and that analysis with a mixed effects model was appropriate. Data were tested for normality, and sediment data did not exhibit a normal distribution but did exhibit a log normal distribution. Therefore, logarithmic transformations were used to normalize sediment data.

Linear regression equations were developed to relate infiltration and sedimentation rates to soil and vegetation measurements. Regression equations were developed using forward and backward stepwise selection in SAS (SAS Institute Inc 2001), and the model was chosen based on Mallow's $C p$ to account for colinearity in model selection. Due to this method of model selection, occasionally variables are included in the regression model with a $P$ value of greater than 0.05 , but never greater than 0.15 . In this text, statistical significance indicates a $P$ value of less than 0.05 unless otherwise stated, and values are presented \pm 1 standard error.

\section{RESULTS}

\section{Wetting and Infiltration}

Ponding and initial runoff times were significantly $(P<0.05)$ slower in the canopy zone than in the interspace area, 


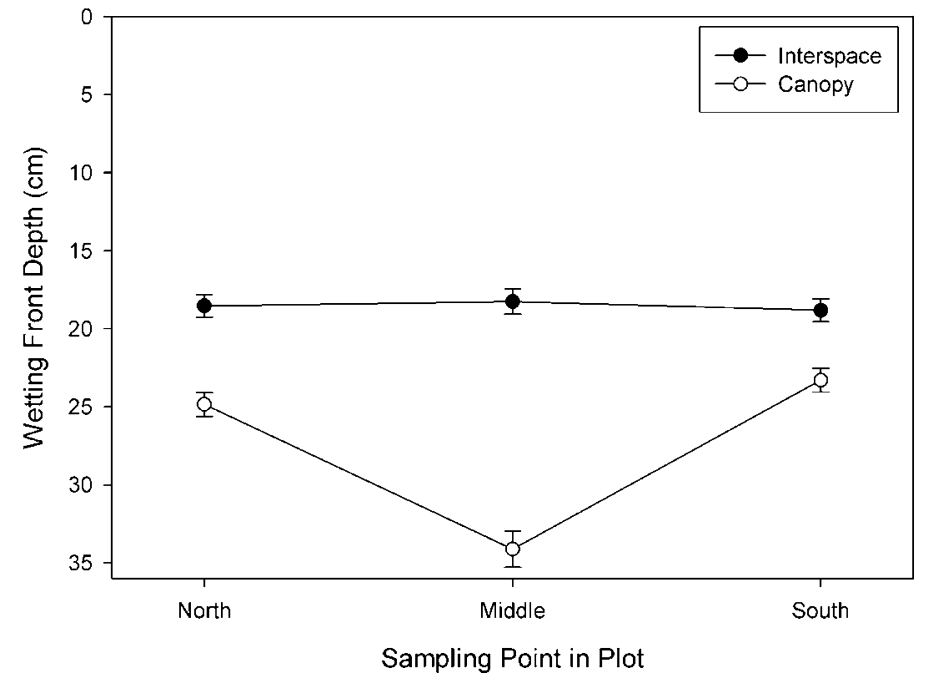

Figure 1. Wetting-front depth in the creosotebush canopy zone and adjacent interspace area, averaged across all geographic regions and herbicide treatments.

irrespective of study location or herbicide treatment. Average time to ponding was $1.45 \pm 0.13$ minute and time to runoff was $2.66 \pm 0.23$ minute in the canopy zone, compared to $0.53 \pm 0.03$ minute and $1.29 \pm 0.06$ minute in the interspace, respectively. Slow ponding and infiltration times suggest greater water movement into the soil profile and this was confirmed by a wetting-front depth that was significantly $(P<0.001)$ deeper in the canopy zone than in the interspace (Fig. 1). In general, the wetting front was a uniform depth across interspace infiltration plots (average $18.5 \pm 0.75 \mathrm{~cm}$ deep), but in the canopy zone the wetting front was much deeper near the plot center than at the outer edge (average $34.1 \pm 1.2 \mathrm{~cm}$ vs. $24.1 \pm 0.8 \mathrm{~cm}$, respectively). The plot center corresponded with the creosotebush base where roots serve as macropores for water transport resulting in a deeper wetting front (Devitt and Smith 2002). There was no statistically significant difference in

Table 1. Terminal infiltration rates $\left(\mathrm{cm} \cdot \mathrm{hr}^{-1}\right.$; mean $\left.\pm \mathrm{SE}\right)$ by region for canopy-interspace areas as influenced by herbicide treatment and creosotebush proximity ${ }^{1}$.

\begin{tabular}{lccc}
\hline & & \multicolumn{2}{c}{ Terminal infiltration } \\
\cline { 3 - 4 } Region & Herbicide treatment & Canopy & Interspace \\
\hline Deming & No treatment & $4.2 \pm 0.6 \mathrm{ab}$ & $2.5 \pm 0.4 \mathrm{ab}$ \\
& $5-9 \mathrm{y}$ & $5.5 \pm 0.5 \mathrm{ab}$ & $2.4 \pm 0.6 \mathrm{ab}$ \\
& $15-18 \mathrm{y}$ & $3.1 \pm 0.6 \mathrm{~b}$ & $1.9 \pm 0.1 \mathrm{ab}$ \\
San Andres & No treatment & $5.8 \pm 0.5 \mathrm{ab}$ & $2.1 \pm 0.5 \mathrm{ab}$ \\
& $5-9 \mathrm{y}$ & $6.7 \pm 0.3 \mathrm{a}$ & $3.6 \pm 0.4 \mathrm{a}$ \\
& $15-18 \mathrm{y}$ & $4.2 \pm 0.5 \mathrm{ab}$ & $1.1 \pm 0.6 \mathrm{ab}$ \\
Mimbres & No treatment & $5.6 \pm 0.6 \mathrm{ab}$ & $0.3 \pm 0.3 \mathrm{~b}$ \\
& $5-9 \mathrm{y}$ & $6.7 \pm 0.7 \mathrm{ab}$ & $0.4 \pm 0.4 \mathrm{~b}$ \\
& $15-18 \mathrm{y}$ & $3.9 \pm 0.9 \mathrm{ab}$ & $1.1 \pm 0.4 \mathrm{ab}$ \\
\hline
\end{tabular}

${ }^{1}$ Means followed by the same letter within each column are not significantly different $(P>0.05)$.
Table 2. Multiple linear regression equations for terminal infiltration in the canopy zone and interspace. Variables are listed in the order in which they entered the model.

\begin{tabular}{lrrrr}
\hline Parameter & Beta $(\beta)$ & $P$ value & \multicolumn{1}{c}{ SE } & $R^{2}$ \\
\hline Canopy & & & & \\
$\quad$ Intercept & 3.479 & $<0.0001$ & 0.566 & 0.40 \\
Litter mass $\left(\mathrm{g} \cdot \mathrm{m}^{-2}\right)$ & 0.036 & .0014 & 0.011 & \\
Shrub aerial cover (\%) & 0.029 & 0.0009 & 0.008 & \\
Litter cover $(\%)$ & 0.098 & 0.0181 & 0.040 & \\
Grass aerial cover (\%) & 0.038 & 0.0226 & 0.016 & \\
Interspace & & & & \\
Intercept & & & & \\
Rock cover $(\%)$ & 2.623 & $<0.0001$ & 0.526 & 0.56 \\
Grass mass (g·m ${ }^{-2}$ ) & 0.037 & 0.0347 & 0.017 & \\
Clay content $(\%)$ & -0.140 & 0.0006 & 0.038 & \\
Grass aerial cover (\%) & -0.075 & 0.0332 & 0.034 & \\
Forb aerial cover (\%) & 0.132 & 0.1242 & 0.084 & \\
Alcohol drop aggregation & -0.203 & 0.0331 & 0.092 & \\
Litter cover (\%) & 0.511 & 0.0060 & 0.176 & \\
\hline
\end{tabular}

wetting-front depth in the canopy zone of live or dead creosotebush treated 5-9 or 15-18 years earlier, suggesting that enhanced percolation is a long-lasting effect in the shrub coppice dune area.

Infiltration rates were always higher in the canopy zone than in the interspace, and there was a significant $(P<0.01)$ interaction between creosotebush proximity (canopy zone vs. interspace) and herbicide treatment (Table 1). Regression equations relating terminal infiltration in the canopy zone to soil and vegetation characteristics were positively correlated with litter mass, and cover of litter, shrub, and grasses (Table 2). Aerial shrub and grass cover is often correlated with interception and stemflow, and greater cover is expected to reduce runoff and increase infiltration (Navar and Bryan 1990; Domingo et al. 1998). Within the canopy zone of live or dead creosotebush, litter accumulation likely had a profound effect on attributes that influence infiltration rate, such as high aggregate stability, organic matter content, and vegetation cover and biomass (Table 3). Presumably, litter age, structure, composition, and depth, in addition to quantity (biomass), directly influences the infiltration rate in coppice dunes, but further research is needed to better understand this relationship. Irrespective of study location, infiltration rates in canopy zones were always highest in 5-9-year-old sites, intermediate in no-treatment sites, and lowest in 15-18-year-old sites (Table 1; Fig. 2).

Infiltration rates in the interspace followed a similar numeric but statistically insignificant $(P>0.05)$ trend to that observed in the canopy zones, with highest rates in 5-9-year-old sites, intermediate in no-treatment sites, and lowest in 15-18-yearold sites (Table 1; Fig. 2). Interspace infiltration rates were positively related to properties that indicate or contribute to soil porosity such as increasing rock and litter cover, aggregate stability, and grass cover. Interspace infiltration was negatively correlated to clay content and, unexpectedly, grass biomass and forb cover (Table 2). 


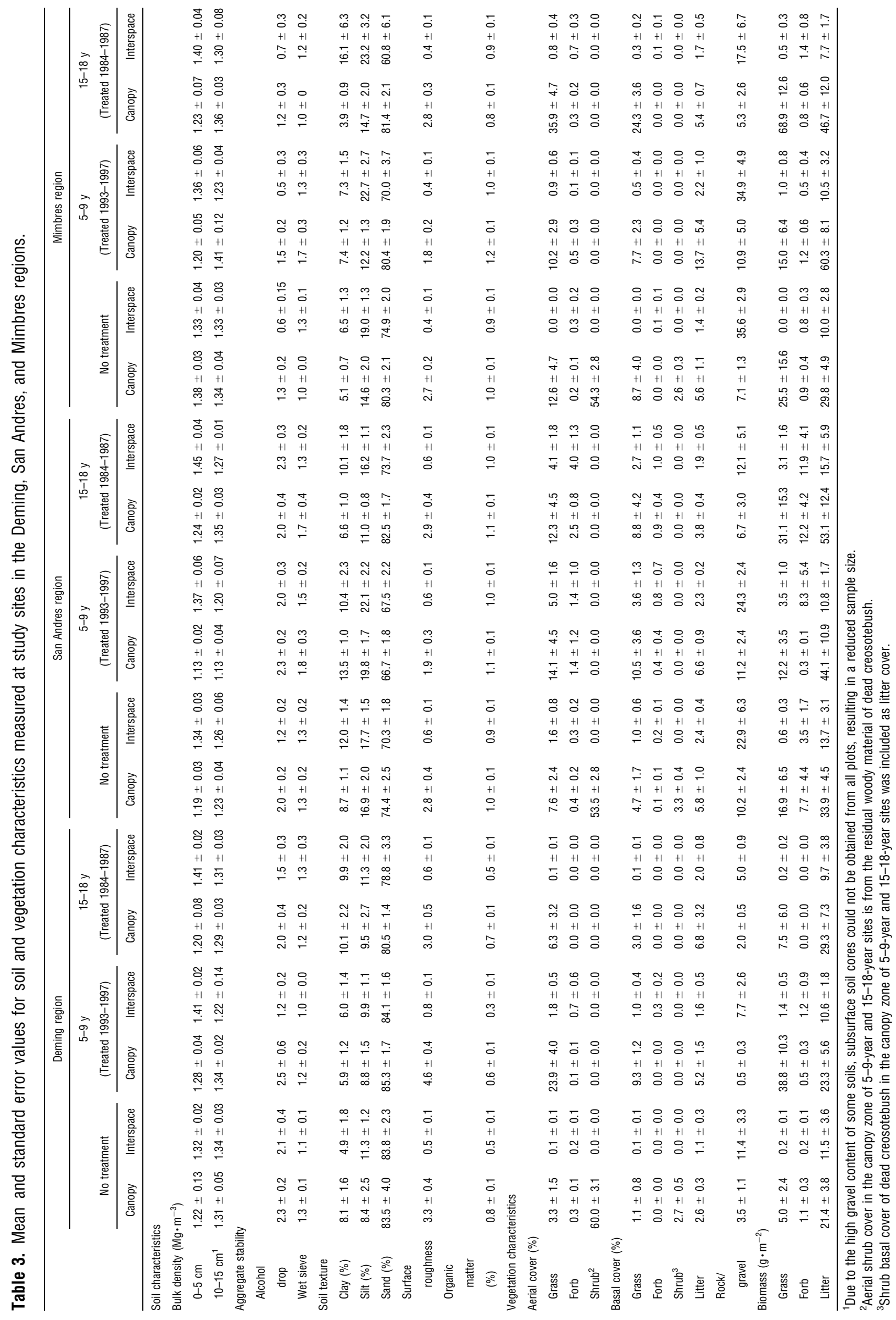




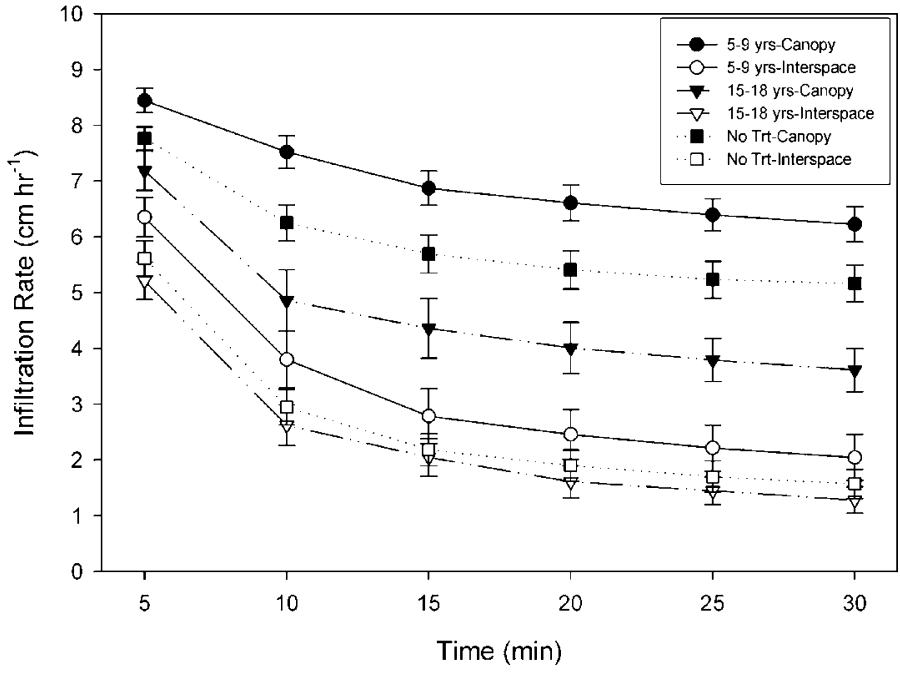

Figure 2. Infiltration rates in the creosotebush canopy zone and adjacent interspace area as influenced by the interaction between herbicide treatment and creosotebush proximity (canopy zone vs. interspace), averaged across all geographic regions.

\section{Sediment}

Sediment concentrations $\left(\mathrm{g} \cdot \mathrm{L}^{-1}\right)$ in runoff were significantly $(P<0.01)$ higher from the canopy zone than from the interspace but were not different by herbicide treatment (Fig. 3). Sediment concentrations were, as expected, especially high during the first 5 to 10 minutes of a run and then decreased with time. Progressive sediment yield was significantly $(P<0.05)$ different by herbicide treatment when averaged across canopy and interspace zones; yield increased with time on 5-9-year sites, remained fairly constant during runs on 1518-year sites, and decreased with time on no-treatment sites (Fig. 4). Total cumulative sediment yield was not significantly $(P<0.05)$ affected by creosotebush proximity, geographic region, or herbicide treatment, and was $347 \pm 44 \mathrm{~kg} \cdot \mathrm{ha}^{-1}$ overall. Total sediment yield was only weakly correlated with

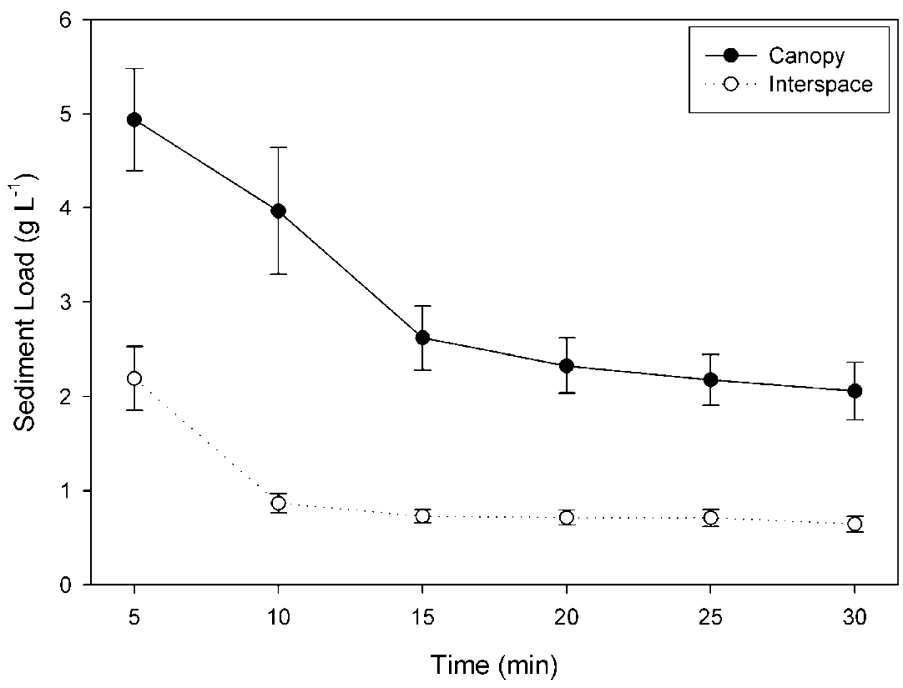

Figure 3. Sediment concentration in runoff from the creosotebush canopy zone and adjacent interspace area, averaged across all geographic regions and herbicide treatments.

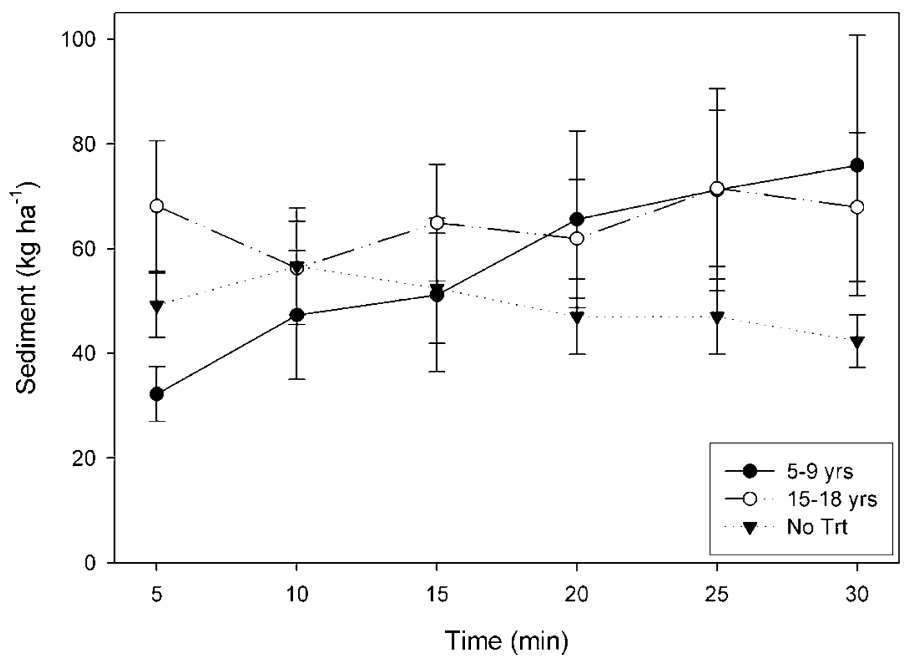

Figure 4. Progressive sediment yield in runoff from creosotebush shrublands as influenced by herbicide treatments, averaged across all geographic regions and canopy/interspace plots.

measured plot parameters, as evidenced by the low $R^{2}$ values (Table 4). In the canopy zone, total sediment yield was correlated with surface roughness, rock cover, and organic matter content. In the interspace, total sediment yield was only correlated with sand content of the soil.

\section{DISCUSSION}

Schlesinger et al. (1990) hypothesized that shrub invasion into productive desert grasslands results in a shift from a relatively uniform distribution of water, nitrogen, and other soil resources across the landscape to an increase in spatial and temporal heterogeneity. Under the Schlesinger et al. (1990) conceptual model for seral retrogression or desertification, increases in the spatial and temporal heterogeneity lead to greater invasions of shrubs into grasslands. Creosotebush control is an intervening action designed in part to reverse this process, and further study is needed to determine how the soil-building process changes once the shrub is removed. Our data suggest there is a slow but gradual shift in certain hydrologic properties after creosotebush control that is largely dictated by the rate of decomposition of litter materials in the canopy zone. However, within the 18 -year posttreatment timeframe of this study it is clear that there is still

Table 4. Multiple linear regression equations for total sediment yield. Variables are listed in the order in which they entered the model.

\begin{tabular}{lrrrr}
\hline Parameter & Beta $(\beta)$ & $P$ value & \multicolumn{1}{c}{ SE } & $R^{2}$ \\
\hline Canopy & & & & \\
$\quad$ Intercept & -13.389 & 0.6726 & 31.543 & 0.13 \\
Surface roughness (SD) & 11.470 & 0.0452 & 5.617 & \\
Rock cover (\%) & -1.607 & 0.0834 & 0.914 & \\
Organic matter (\%) & 33.369 & 0.1428 & 22.501 & \\
Interspace & & & & \\
$\quad$ Intercept & 55.742 & 0.0007 & 15.699 & 0.05 \\
$\quad$ Sand & -0.400 & 0.0598 & 0.209 & \\
\hline
\end{tabular}


a canopy zone influence on the spatial distribution of properties that influences the distribution of water resources across the landscape.

Infiltration rates were consistently higher in creosotebush canopy zones than in interspace areas across all regions and herbicide treatments evaluated (Table 1). This finding corresponds with other studies that have also reported higher infiltration rates in shrub canopy zones than in interspace areas (Brock et al. 1982; Balliette et al. 1986). Infiltration rates were highest in 5-9-year sites, indicating that initially tebuthiuron treatments increase infiltration. However, infiltration rates appear to decrease with time following treatments, as the lowest infiltration rates typically occurred in 15-18-year sites. We speculate that this trend may result from higher leaf and twig contributions to the canopy zone during the defoliation process shortly after herbicide treatment (i.e., 5-9 years). Although Brock et al. (1982) and Balliette et al. (1986) did not report infiltration rate differences in the canopy zone within 5 years of herbicide treatment on mesquite and big sagebrush (Artemisia tridentata Nutt.), our results agree with Wood et al. (1991) who reported a short-term decrease (4 years) in runoff from a creosotebush community treated with tebuthiuron. In our study areas treated 15-18 years earlier, we noted that larger structural branches from dead creosotebush were still being added to the litter pool. However we also noted that finer litter material was diminished and we anticipate, with time, that infiltration rates will continue to decline in the canopy zone as litter material further ages and decomposes.

Creosotebush takes principal advantage of soil water within the canopy zone when living (Sala et al. 1989; Brown and Archer 1990; Dodd et al. 1998), but after the shrub dies other plants, especially bush muhly, rapidly occupy dune areas and take advantage of the water resources (Brock et al. 1982; Perkins 2003). This shift in plant composition is expected to influence specific soil properties associated with infiltration rates and sediment loss, such as aggregate stability, bulk density, and organic matter content (Blackburn et al. 1992). Wood et al. (1998) examined differences in interception rates among Chihuahuan Desert grass and shrub species and attributed major differences to weight and size of plants. In general, increasing plant cover reduces raindrop impact and enhances water infiltration, whereas declines in plant cover elevate soil erosion rates (Tadmor and Shanan 1969; Bergkamp 1998).

In this study, total sediment yield was, in general, poorly correlated with the plot variables measured and was not significantly affected by creosotebush proximity, herbicide treatment, or geographic region. Neave and Abrahams (2001) also found a poor correlation between surface properties and sediment yield from creosotebush canopies and adjacent interspaces. Other studies however, have reported lower sediment yield from canopy zones than from interspace areas due to soil stabilization by shrubs (Brock et al. 1982; Balliete et al. 1986; Johnson and Gordon 1988). The similarity in total sediment yield from the canopy zone and interspace in this study may partially be attributed to the formation of a physical soil crust, which is common in the interspace portion of arid soils but not in canopy zones. Although soil crusts often reduce infiltration and increase runoff rates (McIntyre 1958; Al-Qinna and Abu-Awwad 1998), topsoil is stabilized by the crust and erosion rates are often reduced (Moore and Singer 1990; Roth and Helming 1992).

\section{MANAGEMENT IMPLICATIONS}

A primary goal behind the BLM's creosotebush control program in southern New Mexico is to reverse what has been a gradual expansion of the shrub into areas that were formerly dominated by grasses, especially black grama (Bouteloua eriopoda [Torrey] Torrey) and bush muhly (Buffington and Herbel 1965; Gibbens and Beck 1988). After surveying the nearly 70 different locations treated by the BLM since the early 1980s (Perkins 2003; Perkins et al. 2005) we noted that this brush control practice is likely to produce long-lasting creosotebush control, perhaps 75 years or longer. We observed only minor recruitment of new creosotebush plants on treated areas and in most of the oldest areas surveyed there was an obvious change in the plant community toward herbaceous dominants.

As creosotebush invades grasslands, there is a concomitant change in soil properties (Schlesinger et al. 1990; Perkins et al. 2005) and hydrologic processes. Following creosotebush establishment, brush control treatments can cause a relatively rapid change in vegetation composition and promote the establishment of grasses. However, soil properties and hydrologic processes change much more slowly than vegetation (Perkins et al. 2005). The temporal discontinuity in vegetation, soil, and hydrologic responses to creosotebush control must be recognized in managing natural areas that have been or potentially may be invaded by creosotebush. Although many current creosotebush shrublands were previously grasslands (Buffington and Herbel 1965; Grover and Musick 1990; Van Auken 2000), the soils and hydrology that sustained these grasslands were likely altered following creosotebush establishment. Consequently, revegetation projects designed to control creosotebush and increase grass cover should account for longterm changes in soil properties and hydrologic processes that may be required to create an environment conducive to the establishment and persistence of grasses. Presumably, areas in which creosotebush encroachment has occurred relatively recently will have experienced less change in soils and hydrology than areas that have had creosotebush for a long period of time. Therefore, revegetation efforts may be more successful in areas where creosotebush has recently established, and land managers may want to prioritize creosotebush control projects accordingly.

\section{ACKNOWLEDGEMENTS}

We thank Garrett Timmons, Janet Perkins, Vince Romero, Lauren Cunningham, and Lindsey Hansen, who assisted with data collection and various laboratory analyses. We also thank the Las Cruces Bureau of Land Management district office for their help in this research, especially Jim McCormick and Rich LaCasse, who provided ongoing assistance. We express appreciation to Leigh Murray for assistance with the statistical analysis, and we thank Karl Wood for reviewing an earlier draft of this manuscript and providing valuable input.

\section{LITERATURE CITED}

Abrahams, A. D., A. J. Parsons, and J. Wainwright. 1994. Resistance to overland flow on semiarid grassland and shrubland hillslopes, Walnut Gulch, southern Arizona. Journal of Hydrology 156:431-446. 
Abrahams, A. D., A. J. Parsons, and J. Wainwright. 1996. Effects of vegetation change on interrill runoff and erosion, Walnut Gulch, southern Arizona. Geomorphology 13:37-48.

Al-Qinna, M. I., AND A. M. Aвu-Awwad. 1998. Infiltration rate measurements in arid soils with surface crust. Irrigation Science 18:83-89.

ANDERSON, J. U. 1963. An improved pretreatment for mineralogical analysis of samples containing organic matter. Clays and Clay Minerals 10:380-388.

Azooz, R. H., AND M. A. ARSHAD. 1996. Soil infiltration and hydraulic conductivity under long-term no-tillage and conventional tillage systems. Canadian Journal of Soil Science 76:143-152.

Balliette, J. F., K. C. McDaniel, and M. K. Wood. 1986. Infiltration and sediment production following chemical control of sagebrush in New Mexico. Journal of Range Management 39:160-165.

BeRGKAMP, G. 1998. A hierarchical view of the interactions of runoff and infiltration with vegetation and microtopography in semiarid shrublands. Catena 33 201-299.

Blackburn, W. H., R. O. Meewig, and C. M. Skau. 1974. A mobile infiltrometer for use on rangeland. Journal of Range Management 27:322-323.

Blackburn, W. H., F. B. Pierson, C. L. Hanson, T. L. Thurow, and A. L. Hanson. 1992. The spatial and temporal influence of vegetation on surface soil factors in semiarid rangelands. Transactions of the ASAE 35:479-486.

Blake, G. R., and K. H. HartGe. 1986. Bulk density, In: A. Klute [ed.]. Methods of soil analysis part 1-Physical and mineralogical methods. 2nd ed. Madison, WI: American Society of Agronomy and Soil Science Society of America. p 363-375.

BOWYER-BOWER, T. A. S. 1993. Effects of rainfall intensity and antecedent moisture on the steady-state infiltration rate in a semi-arid region. Soil Use and Management 9:69-76.

Brock, J. H., W. H. BlackBuRn, and R. H. Hass. 1982. Infiltration and sediment production on a deep hardland range site in north central Texas. Journal of Range Management 35:195-198.

BRown, J. R., AND S. ARCHER. 1990. Water relations of a perennial grass and seedling vs adult woody plants in a subtropical savanna, Texas. Oikos 57: 366-374.

Buffington, L. C., AND C. H. Herbel. 1965. Vegetational changes on a semidesert grassland range from 1858 to 1963. Ecological Monographs 35:139-164.

Cox, J. R., M. H. Martin-R., F. A. Ibarra-F., and H. L. Morton. 1986. Establishment of range grasses on various seedbeds at creosotebush (Larrea tridentata) sites in Arizona, U.S.A., and Chihuahua, Mexico. Journal of Range Management 39:540-546.

Dee, R. F., T. W. Box, and E. Robertson, JR. 1966. Influence of grass vegetation on water intake of Pullman silty clay loam. Journal of Range Management 19: 77-79.

DevitT, D. A., AND S. D. Smith. 2002. Root channel macropores enhance downward movement of water in a Mojave Desert ecosystem. Journal of Arid Environments 50:99-108.

Dodd, M. B., W. K. LAUenRoth, AND J. M. WelkeR. 1998. Differential water resource use by herbaceous and woody plant life-forms in a shortgrass steppe community. Oecologia 117:504-512.

Domingo, F., G. Sanchez, M. J. Moro, A. J. Brenner, and J. Puigdefabregas. 1998. Measurement and modeling of rainfall interception by three semi-arid canopies. Agricultural and Forest Meteorology 91:275-292.

Dunkerley, D. L., AND T. L. Booth. 1999. Plant canopy interception of rainfall and its significance in a banded landscape, arid western New South Wales, Australia. Water Resources Research 35:1581-1586.

Gee, G. W., and J. W. Bauder. 1982. Particle-size analysis. In: A. Klute [ed.]. Methods of soil analysis part 1—Physical and mineralogical methods. 2nd ed. Madison, WI: American Society of Agronomy and Soil Science Society of America. p 383-411.

GibBens, R. P., AND R. F. BECK. 1988. Changes in grass basal area and forb densities over a 64-year period on grassland types of the Jornada Experimental Range. Journal of Range Management 41:186-192.

Grover, H. D., And H. B. Musick. 1990. Shrubland encroachment in southern New Mexico, U.S.A.: an analysis of desertification processes in the American southwest. Climatic Change 17:305-330.
Herbel, C. H., H. L. Morton, and R. P. Gibbens. 1985. Controlling shrubs in the arid southwest with tebuthiuron. Journal of Range Management 38:391-394.

Herrick, J. E., W. G. Whitford, A. G. de Soyza, J. W. Van Zee, K. M. Havstad, C. A. SEYBoLd, AND M. WaLton. 2001. Field soil aggregate stability kit for soil quality and rangeland health evaluations. Catena 44:27-35.

Jacoby, P. W., D. N. Ueckert, and F. S. Hartmann. 1982. Control of creosotebush (Larrea tridentata) with pelleted tebuthiuron. Weed Science 30:307-310.

JoHnson, C. W., AND N. D. GoRDon. 1988. Runoff and erosion from rainfall simulator plots on sagebrush rangeland. Transactions of the ASAE 31:421-427.

Kemper, W. D., and R. C. Rosenau. 1986. Aggregate stability and size distribution. In: A. Klute [ED.]. Methods of soil analysis part 1—Physical and mineralogical methods. 2nd ed. Madison, WI: American Society of Agronomy and Soil Science Society of America. p 425-442

Kincaid, D. R., AND G. WilLiams. 1966. Rainfall effects on soil surface characteristics following range improvement treatments. Journal of Range Management 19:346-351.

Martin, S. C., ANd H. L. Morton. 1993. Mesquite control increases grass density and reduces soil loss in southern Arizona. Journal of Range Management 46:170-175.

MclntyRe, D. S. 1958. Permeability measurements of soil crusts formed by raindrop impact. Soil Science 85:185-189.

Mergen, D. E., M. J. Trlica, J. L. Smith, and W. H. Blackburn. 2001. Stratification of variability in runoff and sediment yield based on vegetation characteristics. Journal of the American Water Resources Association 37:617-628.

Moore, D. C., AND M. J. Singer. 1990. Crust formation effects on soil erosion processes. Soil Science Society of America Journal 54:1117-1123.

Morton, H. L., F. A. Ibarra-F, M. H. Martin, and J. R. Cox. 1990. Creosotebush control and forage production in the Chihuahuan and Sonoran deserts. Journal of Range Management 43:43-48.

Navar, J., AND R. BRyan. 1990. Interception loss and rainfall redistribution by three semiarid growing shrubs in northeastern Mexico. Journal of Hydrology 115: $51-63$.

Neave, M., and A. D. Abrahams. 2001. Impact of small mammal disturbances on sediment yield from grassland and shrubland ecosystems in the Chihuahuan Desert. Catena 44:285-303.

Nelson, D. W., AND L. E. Sommers. 1982. Total carbon, organic carbon, and organic matter. In: A. L. Page, R. H. Miller, and D. R. Keeney [EDs.]. Methods of soil analysis, part 2-Chemical and microbiological properties. 2nd ed. Madison, WI: American Society of Agronomy and Soil Science Society of America. p 539-580.

Parizek, B., C. M. Rostagno, and R. Sottini. 2002. Soil erosion as affected by shrub encroachment in northeastern Patagonia. Journal of Range Management $55: 43-48$.

Perkins, S. R. 2003. Effects of chemical creosotebush (Larrea tridentata (D.C.) Cov.) control on vegetation composition, edaphic properties, and hydrologic processes as influenced by successional stage [dissertation]. Las Cruces, NM: New Mexico State University. 197 p.

Perkins, S. R., K. C. McDaniel, and A. L. Ulery. 2005. Vegetation and soil change following creosotebush (Larrea tridentata) control in the Chihuahuan Desert. Journal of Arid Environments (in press).

Quinton, J. N., G. M. Edwards, and R. P. C. Morgan. 1997. The influence of vegetation species and plant properties on runoff and soil erosion: results from a rainfall simulation study in south east Spain. Soil Use and Management 13:143-148.

Roth, C. H., and K. Helming. 1992. Surface seal properties, runoff formation and sediment concentration as related to rainfall characteristics and the presence of already formed crusts. Soil Technology 5:359-368.

Sala, 0. E., R. A. Golluscio, W. K. Lauenroth, and A. Soriano. 1989. Resource partitioning between shrubs and grasses in the Patagonian steppe. Oecologia $81: 501-505$

SAS InSTITUTE, Inc [computer program]. 2001. Statistical Analysis System. Version 8.02. Cary, NC: SAS Institute, Inc

Schlesinger, W. H., J. F. Reynolds, G. L. Cunningham, L. F. Huenneke, W. M. JarRell, R. A. Virginia, AND W. G. Whitford. 1990. Biological feedbacks in global desertification. Science 247:1043-1048. 
Tadmor, N. H., and L. Shanan. 1969. Runoff inducement in an arid region by removal of vegetation. Soil Science Society America Proceedings 33: 790-794.

Taylor, S. A., And G. L. Ashcroft. 1972. Physical edaphology: The physics of irrigated and nonirrigated soils. San Francisco, CA: W. H. Freeman and Company. 533 p.

Thurow, T. L., W. H. BlackBuRn, and C. A. Taylor. 1986. Hydrologic characteristics of vegetation types as affected by livestock grazing systems, Edwards Plateau, Texas. Journal of Range Management 39:505-509.

Tromble, J. M., K. G. Renard, and A. P. Thatcher. 1974. Infiltration for three rangeland soil-vegetation complexes. Journal of Range Management 27: 318-321.

Van Auken, 0. W. 2000. Shrub invasions of North American semiarid grasslands. Annual Review of Ecology and Systematics 31:197-215.

Whitford, W. G. 2002. Ecology of desert ecosystems. New York, NY: Academic Press. 343 p.
Whitford, W. G., J. Anderson, and P. M. Rice. 1997. Stemflow contribution to the 'fertile island' effect in creosotebush, Larrea tridentata. Journal of Arid Environments 35:451-457.

WıLCOX, B. P. 1985. Infiltration and erosion investigations in the Guadalupe Mountains of New Mexico [dissertation]. Las Cruces, NM: New Mexico State University. $185 \mathrm{p}$.

Wilcox, B. P., M. K. Wood, J. T. Tromble, and T. J. Ward. 1986. A hand-portable single nozzle rainfall simulator designed for use on steep slopes. Journal of Range Management 39:375-377.

Wood, M. K., E. L. Garcia, and J. M. Tromble. 1991. Runoff and erosion following mechanical and chemical control of creosotebush (Larrea tridentata). Weed Technology 5:48-53.

Wood, M. K., T. L. Jones, and M. T. Vera-Cruz. 1998. Rainfall interception by selected plants in the Chihuahuan Desert. Journal of Range Management 51:91-96.

World Climate. 2002. World Climate. Available at http://www.worldclimate.com. Accessed 14 August 2002. 